\title{
Experiences with deferred grazing at the Taranaki Agricultural Research Station
}

D.A. McCALLUM', N.A. THOMSON' and T.G. JUDD'

'Taranaki Agricultural Research Station, DRC, Normanby

${ }^{2}$ Flock House Agriculture Centre, MAF Technology, Bulls

\section{Abstract}

Deferred grazing is the practice of holding over pasture in situ that has been considered surplus to animal requirements in spring, to be grazed at a later date when a shortage of pasture occurs, usually in summer/autumn. This non-mechanical method of pasture conservation was developedandpractised from 1986-1989 at the Taranaki Agricultural Research Station as part of a low cost dairy system. At the low stocking rate (3.7 cows/ha) 13\% of the farm area was conserved as deferred grazing and allowed to naturally reseed before grazing. The reseeding doubled the tiller density of perennial ryegrass, increasing pasture growth by $15-19 \%$ the following season. This, combined with the nil cost associated with conserving supplements, made this system more profitable than the traditional haysilage system.

For the natural reseeding to be successful, the deferred grazed pasture should be removed from thegrazingrotationduring theryegrassreproductive phase (mid-October to mid-November) and not grazed until after the ryegrass seed is mature (midJanuary). The method developed to utilise deferred grazed pasture has been to strip graze between the morning and night milkings. Cows are offered a pasture allowance of $10 \mathrm{~kg} \mathrm{DM} / \mathrm{cow} /$ day or one, two hundred and fiftieth of the farm per day, to achieve a utilisation of around 50\%. Cows graze selectively leaving a residual of about $4000 \mathrm{~kg} \mathrm{DM} /$ haofpredominantly dead material. Mowing before grazing increased utilisation, but there was no advantage in milk solids production. No benefits were observed when tall fescue or phalaris pastures were allowed to naturally reseed. Deferred grazing had no effect on grass grub or porina populations if grazed before April. No detrimental animal health effects have been measured with deferred grazing. To reduce farm operating costs and increase pasture growth, it is recommended that $10 \%$ of the farm is deferred and allowed to naturally reseed on an annual basis.
Keywords deferred grazing, pasture conservation, natural reseeding, tiller density, pasture growth, dairy production

\section{Introduction}

On a dairy farm, the conservation of surplus pasture as either hay or silage is a standard management practice. Costs of mechanical conservation account for $18 \%$ of total farm operating expenditure (Thomson et al. 1989) and altematives to present conservation systems are therefore required (Wilson 1987).

Pastures based on perennial ryegrass and white clover are recognised as being the most suitable for dairy farms. Low persistence of perennial ryegrass on high producing dairy farms is a major problem (Thorn \& Prestidge 1988). Lack of ryegrass persistency is possibly due to overgrazing in summer and pasture treading in winter. Also, intensive grazing limits ryegrass regeneration by reseeding. Pasture renovation or renewal is therefore needed to increase ryegrass plant numbers.

The practice of deferred grazing offers a low cost method of pasture conservation and pasture renovation. Pasture considered surplus to cow requirements in spring can be conserved in situ to be grazed at a later date, usually when feed is short in either summer or autumn. Allowing deferred grazed pasture to reseed will result in substantial ryegrass seedling establishment (L'Huillier \&Aislabie 1987). Deferred grazing offers scope therefore for decreased farm expenditure and increased pasture vigour.

Although the concept of deferred grazing is simple, aspects such as when to defer pastures, what pastures to defer, how much to defer, when to graze, how to graze and subsequent grazing management may influence the benefits. At the Taranaki Agricultural Research Station deferred grazing has been practised under experimental and normal farm management conditions. Results and observations will be presented to develop recommenda tions on the management of deferred grazed pasture to maximise animal performance and pasture production at low cost. 
Table 1 Comparison of pasture conservation and no-pasture conservation systems at 3.1 and 4.3 cows/ha

\begin{tabular}{|c|c|c|c|c|}
\hline & \multicolumn{2}{|c|}{$3.7 \mathrm{cows} / \mathrm{ha}$} & \multicolumn{2}{|c|}{$4.3 \mathrm{cows} / \mathrm{ha}$} \\
\hline & Conservation & $\begin{array}{c}\mathrm{N} 0 \\
\text { Conservation }\end{array}$ & Conservation & $\begin{array}{c}\mathrm{N} 0 \\
\text { Conservation }\end{array}$ \\
\hline Milkfat production $\mathrm{kg}$ MF/ha & 570 & 578 & 552 & 521 \\
\hline $\begin{array}{l}\text { Milkprotein production } \mathrm{kg} \text { MP/ha } \\
\% \text { of farm shut for conservation/deferred grazing }\end{array}$ & 412 & 426 & 388 & 366 \\
\hline $\begin{array}{l}\% \text { of farm shut for conservatıon/deferred grazing } \\
\text { Average date harvested or deferred pasture grazed }\end{array}$ & $\begin{array}{c}33 \\
\text { December } 6\end{array}$ & $\begin{array}{c}13 \\
\text { January }\end{array}$ & $\begin{array}{c}17 \\
\text { December } 6\end{array}$ & $\begin{array}{c}3 \\
\text { December } 24\end{array}$ \\
\hline
\end{tabular}

\section{Low cost dairying}

To compare conventional management (20-30 day rotation through spring with surplus pasture conserved as either hay or silage) with no mechanical form of pasture conservation, a farmlet trial was run at the Taranaki Agricultural Research Station from June 1986 to May 1989. The methods and results have been presented by Thomson et al. 1989.

The no conservation farmlet at the low stocking rate (3.7 cows/ha) produced similarmilkfat but superior milk protein (14 kg MP/ha) production per hectare compared with the mechanical conservation farmlet (Table 1). The extra income received from milk solids and the savings through no mechanical conservation of supplements, increased farm profitability by $\$ 360 / \mathrm{ha}$. On average $13 \%$ of the farmlet area was conserved as deferred pasture, with grazing beginning early in January. At the high stocking rate of 4.3 cows/ha, there was a loss of 31 $\mathrm{kg} \mathrm{MF} / \mathrm{ha}$ to the no conservation system, but similar milk protein production compared with the conservation system (Table 1). Only $3 \%$ of the farm area was conserved as deferred grazing with grazing beginning on 24 December.

For the no conservation system to be successful, a moderate stocking rate must be adopted (pasture growth matching cow requirements) and a major proportion of the deferred grazed pasture allowed to reseed (grazed mid-January) (L’Huillier \& Aislabie 1987).

\section{Effects of natural reseeding on pasture performance}

Pasture growth on the farmlet trial paddocks that had been deferred grazed and allo wed to reseed was moni Cored in the following season and compared with that of rotationally grazed pastures. Deferred grazed pastures produced $2.7 \mathrm{tDM} /$ ha more than the rotationally grazed pastures (Table 2). This result is similar to that of L'Huillier (1988) who reported an increase in pasture growth of $3 \mathrm{tDM} / \mathrm{ha}$ in pastures previously reseeded in comparison with those hard grazed. No improvements in DM production were observed in paddocks that had been deferred but grazed before January.
Table 2 Annual pasture production of deferred grazed pastures in farmlet trial in season following deferring vs rotationally grazed pasture ( $\mathrm{DMM} / \mathrm{ha}$ )

Annual pasture production t DM/ha

\begin{tabular}{ll}
\hline Rotationally grazed & 14.0 \\
Deferred grazed & 16.7
\end{tabular}

Table 3 The effects of natural reseeding on pasture performance

\begin{tabular}{|c|c|c|c|}
\hline & $\begin{array}{l}\text { Rotationally } \\
\text { grazed }\end{array}$ & $\begin{array}{c}\text { Deferred } \\
\text { grazed }\end{array}$ & Significance \\
\hline \multicolumn{4}{|l|}{$\begin{array}{l}\text { Ryegrass tiller density } \\
\text { (tillers } / \mathrm{m}^{2} \text { ) }\end{array}$} \\
\hline Spring pre dg & 3850 & 3920 & N S \\
\hline Autumn post dg & 4310 & 9710 & + \\
\hline Spring post dg & 4290 & 7580 & · \\
\hline 12 months post dg & 4690 & 6050 & NS \\
\hline \multicolumn{4}{|l|}{$\begin{array}{l}\text { Pasture production " } \\
\text { following deferring } \\
(\mathrm{kg} \mathrm{DM} / \mathrm{ha})\end{array}$} \\
\hline 1 st winter & 1650 & 1660 & N S \\
\hline Spring & 4410 & 4640 & NS \\
\hline Summer & 3940 & 4420 & N S \\
\hline Autumn & 2360 & 3120 & . \\
\hline Winter & 1420 & 1850 & · \\
\hline Total spring-winter & 12130 & 14030 & $6 \%$ \\
\hline
\end{tabular}

$\mathrm{dg}=$ deferred grazed

To investigate further the benefits of natural reseeding on pasture performance and composition, a small plot trial was run from 1988-1990. Rotationally grazed pasture was compared with deferred grazed pasture that had been removed from the grazing rotation in mid-October, allowed to reseed and first grazed in mid-March. Ryegrass tiller density was similar on the rotationally grazed pasture and deferred grazed pasture in the spring before treatments were applied (Table 3). In the autumn after deferring and reseeding, ryegrass tiller density on the deferred pasture was 5400 tillers $/ \mathrm{m}^{*}$ higher than on the rotationally grazed pasture. This advantage declined to 3290 tillers/m* in the spring and 
1360 tillers $/ \mathrm{m}^{*}$ 12months after deferred grazing. Deferred grazing and natural reseeding had no effect on the other grass or clover component. The increase in ryegrass tiller density in the deferred grazed pastures had a positive effect on pasture growth. There was a small non-significant advantage in growth on the deferred grazed treatment over the first winter, spring and summer after grazing (Table 3). In the subsequent autumn and winter, the deferred grazed pasture produced, respectively, 760 and $430 \mathrm{~kg} \mathrm{DM} / \mathrm{ha}$ more than the rotationally grazed pasture, resulting in an extra $1900 \mathrm{~kg}$ $\mathrm{DM} / \mathrm{ha}$ annual production (spring-winter).

\section{Proportion of the farm to reseed}

At a moderately high stocking rate, the proportion of the farm designated for natural reseeding should not exceed $10 \%$ (Figure 1). For example, if $20 \%$ is removed as deferred grazing and allowed to reseed (not grazed until mid-January), cow requirements would be exceeding pasture growth during December and January, resulting in reduced milk production. If more than $10 \%$ of the farm area is to be removed from the grazing rotation to control surplus growth, it should be grazed or cut for hay or silage by December.

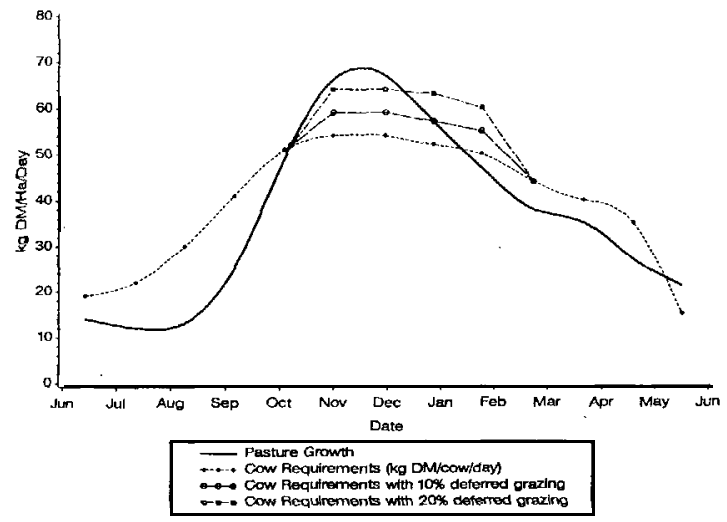

Figure 1 Rate of growth of pastures and cow requirements at 3.7 cows/ha with 10 and $20 \%$ of area removed as deferred grazing.

\section{Time of grazing}

To maximise animal production in deferred grazing systems, deferred pasture should be grazed when cows are short of feed. Grazing of reseeded pasture in late February to early March gave both good seedling establishment and allowed time for the break down of deadmaterial before winter. Earlier grazing (late Januaryearly February) resulted in loss of germinated seedlings if a dry period occurs after grazing. Late grazing (AprilMay) resulted in slow seedling establishment and poor break down of dead material over winter, which appears to restrict winter growth.

\section{Utilisation}

The method developed to utilise deferred grazed pasture has been to strip graze between the morning and night milkings. Cows are offered a pasture allowance of $10 \mathrm{~kg}$ DM/cow/day or one, two hundred and fiftieth of the farm per day to achieve a utilisation of around $50 \%$. At this allowance cows graze reasonably selectively leaving a residual herbage mass of $4 \mathrm{t} \mathrm{DM} / \mathrm{ha}$ of mainly dead material. Milk production will decline in the first 2-3 days of grazing as cows become accustomed to the deferred pasture and its lower digestibility (55\%).

To investigate whether utilisation and reseeding could be improved, a short term grazing trial was conducted in summer 1991, to investigate mowing before grazing. Pasture that had been last grazed in midOctober, was break grazed over 18 days in late January, between the morning and night milkings. Half of the paddock ( $0.25 \mathrm{ha})$ was mown before grazing and on the other half, cows grazed unmown standing pasture. Ten cows wererandomly allocated toeach treatment. Herbage mass of the pasture before grazing or mowing was similar for both treatments (Table 4). After grazing, the residual herbage mass on the mown treatment was 1200 $\mathrm{kg} \mathrm{DM} / \mathrm{ha}$ lower than that of the unmown treatment. This suggested that the apparent pasture intake on the mown pasture was $1.4 \mathrm{~kg} \mathrm{DM} /$ cow/day higher than on the unmown pasture. Milk solids production/cow/day from the two treatments was not significantly different (Table 4). Over the trial period it was observed that cows did not eat freshly mown pasture that had been rained on, until aperiodoffmeweatherhaddrieditout. Milkproduction on the wet days was lower from the mown than from the directly grazed pasture.

Table 4 Grazing vs mowing deferred grazed pasture.

\begin{tabular}{lcll}
\hline & Grazed & Mown Significance \\
\hline $\begin{array}{l}\text { Pre grazing herbage mass } \\
\text { kg DM/ha }\end{array}$ & 8100 & 7900 & . \\
$\begin{array}{l}\text { Grazing residual herbage mass } \\
\text { kg DM/ha }\end{array}$ & 4650 & 3450 & - \\
$\begin{array}{l}\text { Apparent pasture intake } \\
\text { kg DM/cow/day }\end{array}$ & 4.8 & 6.2 & . \\
kg Milkfat/cow/day & 0.48 & 0.46 & $\mathrm{~N} \mathrm{~S}$ \\
kg Milkprotein/cow/day & 0.30 & 0.29 & $\mathrm{~N} \mathrm{~S}$ \\
Pasture re-seeding tillers/m² & 11860 & 13800 & $\mathrm{NS}$ \\
\hline
\end{tabular}

At the subsequent grazing (25 days after first grazing), 8 animals were again randomly allocated to the previous treatments and milk production monitored over the grazing period ( 2 days). There were no effects of the 
previous treatments onmilksolids production. Perennial ryegrass tillerpopulations (assessed from $6.5 \mathrm{~cm}$ cores) from the two treatments, 3 months after the first grazing, were not significantly different.

\section{Insect populations}

To assess whether deferred grazing had any effect on insect populations, grass grub and porina populations were monitored on deferred grazed and rotationally grazed pastures in two small-plot trials. There were no significant differences in grass grub populations between the deferred and rotationally grazed pastures (Table 5). Porina populations in deferred grazed pastures that were grazed in January to March were not significantly different to those in rotationally grazed pastures. However, with later grazing of the deferred pasture (April) the porina populations were higher $(\mathrm{P}<0.06)$ than both the early deferred and the rotationally grazed pasture.

Ferro (1976) reported that rank pastures or pastures left for seed are more prone to porina damage because of the high humidity in the ground, preventing the larvæ from desiccation. This, however, did not influence porinapopulations in January/March grazing of deferred pasture, but may have been the factor influenaing porina populations in the later grazing (April). The results from this trial suggest that if the deferred pasture is grazed betweenmid-Januaryandmid-M archporinapopulations will not be affected.The late-grazed deferred pasture (grazed April) may be an ideal environment for porina survival.

\section{Facial eczema spores}

Facial eczema spore counts were compared under rotationally and deferred grazed pastures in 2 small plot trials and 1 paddock. On average, spore counts were lower indeferrcd grazed pastures thanrotationally grazed pastures (Table 5). Spore counts on both pastures wcre low, and the effect of deferred grazing on spore counts in acute fadial eczema conditions has not been tested. Monitoring of spores is recommended at the time of grazing if conditions are ideal for their establishment.

\section{Deferring of tall fescue and phalaris}

A tall fescue and a phalaris paddock (each 1.0 ha) with low plant densities were removed from the grazing rotation in mid-October, allowed to reseed, and then out for hay in late February 1990. Observations showed good initial germination of the sown species, but very little persistence with an invasion of quicker establishing
Table $\mathbf{S}$ Insect populations and facial eczema spore counts.

\begin{tabular}{|c|c|c|c|c|}
\hline & $\begin{array}{c}\text { Rotationally } \\
\text { arazed }\end{array}$ & $\begin{array}{l}\text { Deferred } \\
\text { arazed }\end{array}$ & & Significance \\
\hline \multicolumn{5}{|l|}{$\begin{array}{l}\text { Grass grub populations } \\
\text { (grass grubs } / \mathrm{m}^{2} \text { ) }\end{array}$} \\
\hline 1 year post dg & 69 & 40 & & N S \\
\hline 2 years post dg & 88 & 28 & & N S \\
\hline \multicolumn{5}{|l|}{$\begin{array}{l}\text { Porina populations } \\
\text { (porina } / \mathrm{m}^{2} \text { ) }\end{array}$} \\
\hline Trial 1 & 4 & \multirow{2}{*}{\multicolumn{2}{|c|}{$\begin{array}{c}6 \text { (grazed March) } \\
0 \text { (grazed Jan) } \\
(20 \text { grazed April) }\end{array}$}} & ) N S \\
\hline Trial 2 & 8 & & & $6 \%$ \\
\hline Facial eczema spores & & $\begin{array}{l}\text { Grazed } \\
\text { January }\end{array}$ & & $\begin{array}{c}\text { Grazed } \\
\text { March/April }\end{array}$ \\
\hline 1990 - February & 13600 & 2500 & & 5000 \\
\hline Trial . March & 42500 & 10000 & & 15000 \\
\hline 1991 Trial & 1670 & 5000 & & 5000 \\
\hline Paddock 1989 & 2800 & & 6000 & \\
\hline Average & 21500 & & 7210 & \\
\hline
\end{tabular}

grasses, mainly poa annua and perennial ryegrass. By spring little change in the density of sown species was noted.

\section{Recommendation}

To achieve the best in cow performance and subsequent pastureproductionthefollowing systemisrecommended.

* shut pasture up mid-October to mid-November.

* shut no more than $10 \%$ of the farm for natural reseeding if at a reasonably high stocking rate.

* grazereseeded,d eferredgrazed pasturesmid-January to mid-M arch.

* during grazing feed animals at maintenance level only

* strip graze -an allowance of $10 \mathrm{~kg} \mathrm{DM} /$ cow/day or one, two hundred and fiftieth of the farm/ day.

* utilise $50 \%$ then put cows back on the non deferred pasture for the rest of the day.

\section{Conclusion}

Deferred grazing is a cheap and flexible form of pasture conservation. Feeding off the deferred grazed pasture when feed is short will mean cows are fed to requirements throughout summer and autumn. Allowing $10 \%$ of the total farm area to naturally reseed annually will increase the perennial ryegrass component of pastures which will subsequently increase pasture growth, provided the pasture is managed for good seedling establishment. 


\section{ACKNOWLEDGEMENTS}

G. Engelen and farm and technical staff of the Taranaki Agricultural Research Station.

REFERENCES

L'Huillicr, P. 1988. Reduced input spring-summer pasture management options. Proceedings of the Ruakura Farmers Conference 40: 19-25.

L'Huillier, P.J.; A islabie,D.W. 1988. Natural reseeding in perennial ryegrass/white clover dairy pastures. Proceedings of the NZ Grassland Association 49: 111-115.

Thorn, E.R.; Prestidge, R.A. 1988. High performance pastures for high quality cows? Proceedings of the Ruakura Farmers Conference 40: 13- 17.

Thomson N.A.; McCallum D.A.; Prestidge, R. 1989. Is making hay or silage worth the effort? Proceedings of the Ruakura Farmers Conference 44: 50-56.

Wilson J.P. 1988. Winter grazing versus supplements cheaper dairying systems. Proceedings of the NZ Grassland Association 49: 11- 14. 